\title{
Penggunaan Flash Card Dalam Meningkatkan Penguasaan Kosakata Bahasa Inggris Peserta Didik
}

\section{K. Wati ${ }^{1 *}$, I.G Oka ${ }^{2}$, N. N. Padmadewi ${ }^{3}$}

${ }^{12}$ Jurusan Pendidikan Bahasa Inggris Universitas Pendidikan Ganesha

\section{ART I CLE I N F O}

Received January 21, 2021

Revised February 03, 2021

Accepted April 08, 2021

Available online May 25, 2021

\section{Kata Kunci:}

Kosakata

Keywords:

English, Flashcard, Vocabulary
Article history:

Bahasa Inggris, Flashcard,

\begin{abstract}
A B S T R A K
Kemampuan berbahasa Inggris penting karena kemampuan ini memberikan pengaruh secara akademis. Kemampuan bahasa Inggris dapat dilihat dari kekayaan kosakata yang dimiliki seseorang. Salah satu upaya kreatif dalam pembelajaran agar menarik yaitu menggunakan media flash cards. Penelitian ini bertujuan untuk mengetahui penggunaan media flash cards dalam meningkatkan kosakata peserta didik pada tingkat SMA. Metode penelitian ini adalah penelitian tindakan kelas. Subjek penelitian adalah 34 siswa kelas XI. Hipotesis penelitian ini adalah peningkatan penguasaan kosakata peserta didik dalam pembelajaran menggunakan media flash card. Hasil pada siklus pertama terjadi peningkatan penguasaan kosakat pada peserta didik yang semula 38,23\% menjadi $58,82 \%$ dan pada siklus kedua terjadi peningkatan prosentase dari $58,82 \%$ menjadi $82,35 \%$. Hal tersebut menunjukkan bahwa flash cards dapat meningkatkan kosakata bahasa Inggris siswa.
\end{abstract}

\section{A B S T R A C T}

English proficiency is important because this ability has an academic influence. The English proficiency can be seen from the learner's vocabulary. One of the best way in interesting learning is using media, such as flash cards. This research aims to determine the use of flash cards in improving the vocabulary of learners at high school level. This method of research is classroom action research. The research subject is 34 students of XI grader. The research hypothesis is increasing the vocabulary of learners in learning using Flash card media. The results for first cycle shows that the mastery of learner's vocabulary improved from $38,23 \%$ to $58,82 \%$ and the second cycle the learners' improved from 58,82\% to $82,35 \%$. It shows that flash cards can improve students 'English vocabulary.

\section{Pendahuluan}

Teori pendidikan merupakan landasan dan pijakan awal dalam pengembangan praktik pendidikan, misalnya pengembangan kurikulum, manajemen sekolah dan proses belajar mengajar. Kurikulum dan pembelajaran memiliki keterkaitan dengan teori pendidikan atau dalam penyusunan suatu kurikulum dan rencana pembelajaran ini mengacu pada teori pendidikan (Sholichah, 2018). Pendidikan adalah suatu usaha sadar dan terencana untuk mewujudkan suasana belajar dan proses pembelajaran agar peserta didik da pat aktif mengembangkan potensinya. Sekolah merupakan lembaga formal yang berfungsi mem bantu khususnya orang tua dalam memberikan pendidikan kepada anak-anak mereka. Pendidi kan memberikan pengetahuan, keterampilan dan sikap kepada anak didiknya secara lengkap sesuai dengan yang mereka butuhkan. Pemerintah telah menetapkan Undang-undang Nomor 20 Tahun 2003 tentang Sistem Pendidikan Nasional. Da lam UU tersebut SPN terdapat beberapa potensi akademik yang akan dikembangkan, dimana po tensi tersebut berkaitan dengan karakter. Hal ter sebut dijabarkan dalam pasal 3 UU SPN bahwa "Pendidikan nasional berfungsi mengembangkan kemampuan dan membentuk watak serta perada ban bangsa yang bermartabat dalam rangka men cerdaskan kehidupan bangsa, bertujuan untuk berkembangnya potensi peserta didik agar men jadi manusia yang beriman dan bertakwa kepada Tuhan Yang Maha Esa, berakhlak mulia, sehat, berilmu, cakap, kreatif, mandiri, dan menjadi warga negara yang demokratis serta bertanggung jawab" (Hasil et al., 2012).

Salah satu masalah yang menarik untuk dikaji berkaitan dengan penguasaan bahasa Inggris yang baik adalah mengenai tata bahasa (grammar). Fungsi bahasa yang utama adalah untuk berkomunikasi. Dalam berkomunikasi setiap pembicara tentulah berusaha agar apa yang ada didalam pikirannya dapat tersampaikan dengan baik dan jelas. Ia ingin agar pesannya dapat dipahami dengan baik oleh pendengar. Namun, hal ini seringkali sulit dilakukan, proses penyampaian pesan sering terhambat karena beberapa factor, misalnya adanya gangguan dan keterbatasan kemampuan bahasa (mencakup tata bahasa dan kosakata) yang sering dialami oleh pembelajar bahasa (Santosa, 2017). 
Bahasa Inggris disebut juga bahasa kedua atau second language, karena bahasa Inggris merupakan bahasa sasaran yaitu bahasa yang sengaja dipelajari dengan tujuan tertentu (Brown, 2008). Hal tersebut yang mendasari pertimbangan bahasa Inggris mulai diberikan pada siswa Sekolah Dasar (bsnpindonesia.org). Permendiknas RI. No 23 tahun 2006 menyatakan bahwa Sekolah Dasar dapat menjadikan bahasa Inggris sebagai mata pelajaran muatan lokal. Bahasa Inggris merupakan bahasa Internasional dan juga merupakan bahasa pengantar untuk sebagian besar pendidikan primer, sekunder dan tersier bagi anak-anak yang mempelajari bahasa Inggris di usia sekolah (Fitriyani and Nulanda, 2017). Bahasa Inggris sebagai bahasa asing di Indonesia mulai menjadi perhatian khususnya di area pendidikan dasar sejak awal tahun '90an yang didasari atas kesadaran pentingnya mempelajari bahasa inggris sedini mungkin untuk bisa turut bersaing di dunia yang semakin modern dan global. Kesadaran tersebutlah yang akhirnya membuat pemerintah mengeluarkan kebijakan melalui Departemen Pendidikan dan Kebudayaan Republik Indonesia (Depdikbud RI) No. 0487/1992, Bab VIII yang menyatakan bahwa SD dapat menambahkan mata pelajaran dalam kurikulumnya (Kulsum, 2016). Kebijakan tersebutlah yang akhirnya mendasari masuknya mata pelajaran bahasa inggris sebagai bagian dari muatan lokal di SD (Faridatuunnisa, 2020). Proses belajar Bahasa Inggris tidak sulit, akan tetapi tidak semudah membalik telapak tangan, yang penting adalah kemauan dan ketekunan. Jika kita belajar bahasa Inggris maka kita harus sering menggunakannya. Pada umumnya akan lebih cepat menguasai Bahasa Inggris. Pada dasarnya kita sering mengaplikasikannya dalam keseharian kita, dikarenakan Bahasa Inggris telah menjadi bagian yang tidak terpisahkan dari kehidupan kita. Demikian

juga yang harus kita terapkan di Indonesia, jika kita ingin belajar Bahasa Inggris dengan efektif, kita harus mengaplikasikan Bahasa Inggris sebagai bagian dari kehidupan kita (Nasution, D., 2021)

Terdapat empat komponen dalam mempelajari bahasa, yaitu keterampilan mendengarkan, berbicara, membaca, dan menulis. Namun sebelum menguasai keterampilan berbahasa tersebut, peserta didik harus menguasai kosa kata dalam bahasa inggris untuk menunjang ke-empat keterampilan berbahasa tersebut. Berdasarkan silabus pendidikan kurikulum 2013 tingkat SMA/SMK/MA mengenai target kelulusan siswa SMA/SMK/MA ke-empat keterampilan berbahasa perlu dikuasai untuk melengkapi keterampilan berbahasa yang terintegrasi. Dengan demikian, peserta didik harus lebih dulu memiliki kosa kata yang kaya sebelum menguasai keterampilan berbahasa tersebut.

Pembelajaran Bahasa Inggris secara umum harus mencapai tujuan pendidikan yang telah tertuang dalam kurikulum pemerintah saat ini, yakni Kurikulum 2013. Tujuan pengajaran Mata Pelajaran Bahasa Inggris dalam Kurikulum yang berlaku saat ini mencakup; mengembangkan kemampuan berkomunikasi dalam bahasa tersebut baik lisan maupun tulis. Kemampuan tersebut meliputi mendengarkan (listening), berbicara (speaking), membaca (reading), dan menulis (writing), yang kedua menumbuhkan kesadaran akan hakikat dan pentingya bahasa Inggris sebagai salah satu bahasa asing untuk menjadi alat utama belajar serta mengembangkan pemahaman keterkaitan antara bahasa dan budaya serta memperluas cakrawala budaya. Dengan demikian siswa memiliki wawasan lintas budaya dan melibatkan diri dalam keragaman budaya. Demi mewujudkan tercapainya tujuan pendidikan tersebut, diperlukan kerjasama antar pelaku pendidikan, dalam hal ini adalah pendidik (guru) dan peserta didik.

Maka dengan memiliki dan menguasai kosakata Bahasa Inggris yang memadai peserta didik akan lebih mudah dalam menguasai keempat keterampilan berbahasa yang akan megantarkannya mencapai tujuan pendidikan tersebut. Namun demikian, berdasarkan observasi yang dilakukan oleh tim guru menemukan bahwa lebih dari 50\% peserta didik belum menguasai keterampilan penguasaan kosakata. Hal ini dibuktikan dengan hasil tes ulangan harian I peserta didik yang mendapat nilai terendah pada soal synonim dan kosakata. Hal ini menyebabkan nilai akhir dari ulangan tersebut belum mencapai nilai KKM (Kriteria Ketuntasan Minimal).

Kemampuan kosa kata pada mata pelajaran Bahasa Inggris memegang peranan penting dalam memahami materi yang akan diajarkan. Hal ini dikarenakan kemampuan penguasaan kosa kata merupakan dasar dalam mempelajari suatu bahasa.Kosakata memiliki manfaat dan peran penting ilmu bahasa, pentingnya menguasai kosakata ini dikarenakan karena tanpa adanya penguasaan kosakata yang cukup, seseorang tidak akan mampu mengutarakan ide dan merespon bahasa yang diterimanya. Pembelajaran kosakata Bahasa Inggris biasanya dilakukan secara terintegrasi dengan keterampilanketerampilan lain seperti membaca, menulis, berbicara, dan mendengarkan. Pembelajaran kosakata tidak dilakukan secara khusus pada waktu pembelajaran karena kosakata ada pada setiap keterampilan berbahasa itu sendiri. Pengajaran kosakata oleh karenanya hendaknya dikaitkan dengan fungsi bahasa sebagai alat komunikasi. Kosakata hendaknya tidak dipandang sebagai daftar panjang kata-kata yang harus didefinisikan dan dihafalkan. Sebaliknya, kosakata hendaknya dilihat peran pentingnya dalam penggunaan bahasa secara kontekstual dan bermakna.

Namun demikian, berdasarkan observasi yang dilakukan oleh tim guru ditemukan bahwa lebih dari $50 \%$ peserta didik belum menguasai keterampilan penguasaan kosakata. Hal ini dibuktikan dengan hasil 
tes ulangan harian I peserta didik yang mendapat nilai terendah pada soal synonim dan kosakata. Hal ini menyebabkan nilai akhir dari ulangan tersebut belum mencapai nilai KKM (Kriteria Ketuntasan Minimal).

Ada beberapa faktor yang menyebabkan rendahnya tingkat penguasaan kosakata pada peserta didik, diantaranya adalah faktor guru dan peserta didik. Berdasarkan hasil observasi yang didapat oleh peneliti, beberapa peserta didik masih membuka membuka kamus untuk menerjemahkan kosakata sulit dalam teks Bahasa Inggris. Metode ini dirasa kurang efektif dalam penguasaan kosakata peserta didik. Karena apabila menggunakan kamus, peserta didik hanya mengetahui arti dari kata tersebut tanpa memahami makna atau persamaan kata dalam bahasa inggris. Sementara guru lebih banyak memberikan latihan-latihan teks membaca tanpa membiarkan peserta didik memahami kosakata sulit dalam teks lebih dalam (Sekarini, 2018).

Beberapa solusi bisa digunakan untuk mengatasi masalah tersebut. Teknik atau strategi ini diharapkan mampu meningkatkan kemampuan siswa dalam penguasaan kosakata Bahasa Inggris. Salah satu strategi tersebut adalah pembelajaran menggunakan media flashcard. Media flashcard adalah media dalam bentuk kartu yang didalamnya diberikan gambar atau petunjuk-petunjuk tertentu dengan tujuan memudahkan peserta didik dalam mempelajari suatu materi pelajaran. Menurut (Arsyad, 2011) Flash card adalah kartu kecil berisi gambar, teks, atau tanda simbol yang mengingatkan atau mengarahkan siswa kepada sesuatu yang berhubungan dengan gambar. Media flash card merupakan salah satu dari media visual. Flash card merupakan kartu yang berisi simbol, tanda, gambar, kata-kata maupun defini yang digunakan sebagai media dalam membantu peserta didik memahami suatu materi pembelajaran.Media pembelajaran menggunakan flashcard adalah media pembelajaran yang sangat familiar dalam meningkatkan penguasaan kosakata dalam berbahasa. Hal ini dikarenakan Flashcard merupakan kartu bergambar yang membantu siswa dalam menguasai materi pembelajaran. (Ahmad Susanto, 2011) mengemukakan bahwa Flashcard adalah kartu-kartu bergambar yang dilengkapi katakata.Penggunaan media pembelajaran selama proses pembelajaran sangat memengaruhi semangat dan minat belajar bagi peserta didik. Hal itu dapat memberikan motivasi belajar bagi peserta didik sebelum kegiatan pembelajaran dimulai.

Media flashcard adalah media pembelajaran dalam bentuk kartu bergambar yang ukurannya sekitar $25 \times 30 \mathrm{~cm}$. Gambar yang ada pada media ini merupakan rangkaian pesan yang disajikan dengan keterangannya (Indriana, 2011). Sedangkan Chatib (2011), menjelaskan bahwa media Flashcard adalah kartu yang berisi gambar atau tulisan berhubungan dengan konsep. Definisi lain diungkapkan oleh Windura (2010), bahwa media flashcard atau kartu kilas adalah kartu yang digunakan untuk mengingat dan mengkaji ulang dalam proses belajar. Jadi, media flashcard merupakan media yang membantu dalam mengingat dan mengkaji ulang bahan pelajaran seperti: definisi atau istilah, simbol-simbol, ejaan bahasa asing, rumus-rumus, dan lain-lainKelebihan media flashcard yang dijelaskan oleh Indriana (2011) dan Riyana dan Susilana (2009) yang pertama adalah mudah dibawa kemana-mana karena ukurannya yang tidak besar dan ringan. Kedua adalah praktis dalam membuat dan menggunakanya, sehingga kapan pun anak didik bisa belajar dengan baik menggunakan media ini. Ketiga, media flashcard juga gampang diingat karena kartu ini bergambar dan sangat menarik perhatian, memuat huruf atau angka yang simpel, sehingga merangsang otak untuk lebih lama mengingat pesan yang ada. Media ini sangat menyenangkan untuk digunakan sebagai media pembelajaran, bahkan dapat digunakan dalam bentuk permainan (Maryanto and Wulanata, 2018).

Azhar Arsyad dalam Sekarini (2018) menyebutkan bahwa Pemakaian media pembelajaran dalam proses belajar mengajar dapat membangkitkan keinginan dan minat yang baru, membangkitkan motivasi dan rangsangan kegiatan belajar, dan bahkan membawa pengaruh-pengaruh psikologi terhadap peserta didik. Kelebihan dari penggunaan media flash card adalah peserta didik merasa terbantu dengan adanya kartu yang beragam dan petunjuk-petunjuk yang diberikan guru melalui kartu tersebut. Media pembelajaran flash card menurut Susilana dan Riyana (2008) memiliki sejumlah kelebihan, yakni: "(1) mudah dibawa-bawa; (2) praktis; (3) gampang diingat; dan (4) menyenangkan".Berdasarkan penjelasan diatas, maka peneliti menggunakan model pembelajaran menggunakan media flashcard dalam upaya meningkatkan kemampuan penguasaan kosa kata peserta didik untuk mendapatkan hasil yang baik dalam peningkatan kemampuan penguasaan kosa kata peserta didik selama proses pembelajaran.

Hasil dari penelitian diharapkan mampu memberikan manfaat bagi guru, peserta didik, sekolah, dan peneliti sendiri sebagai upaya peningkatan pembelajaran dalam kelas. Berdasarkan penjelasan mengenai kelebihan penggunaan media Flash Card, maka peneliti menggunakan media Flash dalam pembelajaran kosakata (vocabulary). Berikut adalah langkah-langkah penggunaan media flashcard yang dikemukakan oleh Rudi Susilana dan Cepi Riyana, antara lain; kartu yang disusun di pegang setinggi dada dan menghadap ke depan siswa, cabutlah satu persatu kartu setelah pendidik selesai menerangkan di depan kelas, berikan kartu-kartu yang telah diterangkan tersebut kepada siswa yang duduk berdekatan dengan guru. Mintalah siswa untuk mengamati kartu tersebut satu persatu, lalu teruskan kepada siswa 
yang lain sampai semua siswa kebagian, jika sajian dengan cara permainan, letakkan kartu-kartu tersebut dalam sebuah kotak secara acak dan tidak perlu disusun, siapkan siswa yang akan berlomba misalnya tiga orang berdiri sejajar, kemudian guru memberikan perintah (instruksi).

Sebelum memulai pembelajaran menggunakan media flash card, terlebih dahulu guru menjelaskan teknis dan aturan permainan flash card. Berikut langkah-langkah penerapan kartu flash card kepada siswa yang disadur dari indonesia mengajar.org. dalam (Alamsyah Said dan Andi Budimanjaya), antara lain; guru membagikan kartu flash card kepada setiap siswa dalam keadaan tertutup. (bagian yang berisi tulisan menghadap ke bawah). Siswa tidak diperbolehkan membuka sebelum aba-aba diberikan), guru memberikan aba-aba dan siswa membuka kartu secara bersamaan, siswa mencari barisannya berdasarkan kartu yang dipegangnya. (aktivitas mencari barisan berdasarkan kartu dilakukan tanpa suara), guru memberikan batas waktu. Jangan lupa hitung mundur ketika waktu sudah hampir selesai, guru mengajak siswa untuk mengecek setiap barisan-barisan, apakah semua siswa telah masuk ke barisan yang seharusnya, guru memberikan apresiasi kepada barisan yang telah benar dan lengkap.

Berdasarkan beberapa yang telah disebut diatas, maka dapat disimpulkan bahwa penggunaan media FlashCard sangat mudah dan dapat diaplikasikan dikelas kecil maupun besar, serta dapat digunakan peserta didik dalam aktivitas kelas, berkelompok, dan kerja berpasangan.

\section{Metode}

Penelitian ini dilakukan menggunakan rancangan penelitian tindakan kelas (PTK). Peneliti menggunakan penelitian tindakan untuk meningkatkan kemampuan penguasaan kosakata Bahasa Inggris pada peserta didik.

Berikut adalah tiga prinsip penelitian tindakan kelas menurut (Kunandar, 2008), antara lain:

a. Adanya partisipasi dari peneliti dalam suatu program atau kegiatan

b. Adanya tujuan untuk meningkatkan kualitas suatu program atau kegiatan melalui penelitian tindakan tersebut, dan

c. Adanya tindakan (treatment) untuk meningkatkan kualitas suatu program atau kegiatan.

Dalam penyusunan desain dan prosedur penelitian tindakan kelas perlu dirumuskan terlebih dahulu rencana berdasarkan informasi yang lebih lengkap dan lebih kritis. Ada empat aspek pokok dalam penelitian tindakan kelas yang harus diperhatikan yaitu penyusunan program, tindakan, observasi dan refleksi. (Sumini)

Dalam penelitian ini, peneliti menggunakan beberapa tahapan, antara lain siklus pertama dan kedua.

a. Siklus I

Siklus I terdiri dari beberapa tahapan, antara lain; perencanaan, yakni peneliti mempersiapkan rencana pelaksaan pembelajaran, lembar kerja siswa, dan lembar observasi pelaksanaan metode penggunaan flashcard, tahap kedua adalah tindakan, dimana pelaksanaan tindakan pada siklus pertama dilakukan dalam dua kali pertemuan. Tahap tindakan dilakukan oleh guru dengan menerapkan metode pembelajaran menggunakan flashcard. Materi yang akan diberikan adalah materi tentang explanation text. Adapun tindakan yang dilakukan pada siklus ini meliputi; pendahuluan, kegiatan inti, dan penutup. Tahap berikutnya adalah observasi yang dilakukan selama proses pembelajaran dengan mencatat hal-hal yang diamati selama kegiatan pembelajaran dan aktivitas guru maupun siswa selama pelaksanaan pembelajaran, tahapan terakhir adalah dimana tahapan ini dilakukan sebagai bahan evaluasi dari pelaksanaan tindakan pada siklus I yang digunakan sebagai bahan pertimbangan perencanaan pembelajaran siklus berikutnya. Apabila hasil yang diharapkan belum tercapai maka dilakukan perbaikan yang dilaksanakan pada siklus kedua dan seterusnya.

b. Siklus II

Tahapan penelitian pada siklus II akan dilaksanakan berdasarkan hasil refleksi pada siklus sebelumnya. Apabila pada siklus I telah mencapai target indikator keberhasilan, maka siklus II akan dilakukan sebagai upaya konfirmasi atas hasil refleksi siklus I. Namun apabila target indikator keberhasilan belum tercapai, maka akan dilakukan perlakuan/tindakan pada siklus II untuk mencapai target indikator keberhasilan. Tahapan pada siklus II terdiri dari perencanaan, tindakan, observasi, dan refleksi.

Dalam penelitian ini, peneliti menggunakan teknik pengumpulan data secara kualitatif dan kuantitatif. Peneliti menggunakan data kualitatif melalui lembar observasi, sementara data kuantitatif menggunakan tes hasil peningkatan kemampuan penguasaan kosakata peserta didik.

Teknik analisis data yang digunakan peneliti dalam penelitian ini adalah teknik analisis data secara kualitatif dan kuantitatif. 
Pada data kualitatif, peneliti menggunakan hasil observasi selama penelitian tindakan kelas ini dilaksanakan. Data akan dikumpukan berdasarkan hasil observasi selama proses pembelajaran dan akan dijelaskan melalui deskripsi singkat. Setelah evaluasi data dilakukan, peneliti dapat menemukan apakah metode yang digunakan dapat meningkatkan penguasaan kosakata Bahasa Inggris peserta didik pada setiap siklus yang dilakukan.

Pada data kuantitatif, peneliti menggunakan hasil Ulangan Harian III (explanation text) pada soalsoal sinonim untuk mengetahui seberapa besar peningkatan yang terjadi pada metode pembelajaran menggunakan flashcard dalam meningkatkan penguasaan kosakata Bahasa Inggris peserta didik. Rumus dalam menentukan prosentase peningkatan kemampuan pada peserta didik dalam kelas adalah sebagai berikut:

$$
P=\frac{F}{N} \times 100 \%
$$

Keterangan:

$\mathrm{P}=$ Prosentase

$\mathrm{F}=$ Jumlah siswa yang mencapai KKM (Kriteria Ketuntasan Minimal)

$\mathrm{N}=$ Jumlah siswa dalam kelas

Pada penelitian tindakan kelas ini jika penggunaan flashcard diterapkan pada proses pembelajaran untuk meningkatkan kemampuan penguasaan kosakata Bahasa Inggris peserta didik maka akan terjadi peningkatan dalam penguasaan kosakata peserta didik sehingga $75 \%$ siswa dalam kelas bisa mencapai nilai KKM (Kriteria Ketuntasan Minimal) yang diharapkan.

\section{Hasil Dan Pembahasan}

Nilai Penelitian ini menggunakan media flash card yang terdiri dari dua siklus. Dalam penelitian ini menunjukkan hasil yang signifikan yakni meningkatnya kualitas proses dan hasil belajar peserta didik pada kemampuan penguasaan kosakata Bahasa Inggris peserta didik. Tindakan yang dilakukan pendidik dengan menggunakan media flash card, dimana pembelajaran ini menekankan kepada kemampuan peserta didik dalam memahami makna kosakata yang ada dalam teks melalui penggunaan media flash card yang dijadikan sebagai konsep-konsep untuk mendukung proses belajar mengajar menggunakan media serta keberanian siswa dalam belajar serta keberanian siswa dalam memperkaya kosakata. Penerapan pembelajaran menggunakan media flash card menjadikan peserta didik lebih mudah memahami kosakata sulit dalam teks yang digunakan selama pembelajaran. Penulis memperoleh data dari hasil Ulangan Harian I peserta didik dengan tipe soal persamaan kata (sinonim). Pada bagian ini lebih dari 50\% peserta didik dalam kelas belum mencapai nilai Kriteria Kentuntasan Minimal (KKM) yaitu 68. Berikut adalah tabel daftar nilai yang diperoleh peserta didik pada Ulangan Harian I dengan materi Personal Letter pada soal bagian B dengan tipe soal persamaan kata (sinonim).

Tabel 1. Daftar nilai awal peserta didik

\begin{tabular}{llll}
\hline No & Daftar Peserta Didik & Nilai Awal & Nilai KKM (68) \\
\hline 1 & Peserta didik nomor 1 & $60^{*}$ & 68 \\
2 & Peserta didik nomor 2 & $60^{*}$ & 68 \\
3 & Peserta didik nomor 3 & $\mathbf{5 0}^{*}$ & 68 \\
4 & Peserta didik nomor 4 & 70 & 68 \\
5 & Peserta didik nomor 5 & $60^{*}$ & 68 \\
6 & Peserta didik nomor 6 & 70 & 68 \\
7 & Peserta didik nomor 7 & $50^{*}$ & 68 \\
8 & Peserta didik nomor 8 & $40^{*}$ & 68 \\
9 & Peserta didik nomor 9 & $55^{*}$ & 68 \\
10 & Peserta didik nomor 10 & $60^{*}$ & 68 \\
11 & Peserta didik nomor 11 & $45^{*}$ & 68 \\
12 & Peserta didik nomor 12 & $65^{*}$ & 68 \\
13 & Peserta didik nomor 13 & 70 & 68 \\
14 & Peserta didik nomor 14 & $40^{*}$ & 68 \\
15 & Peserta didik nomor 15 & $65^{*}$ & 68 \\
16 & Peserta didik nomor 16 & 90 & 68 \\
17 & Peserta didik nomor 17 & $60^{*}$ & 68 \\
18 & Peserta didik nomor 18 & 70 & 68 \\
19 & Peserta didik nomor 19 & 68 & \\
\hline
\end{tabular}




\begin{tabular}{llll}
\hline 20 & Peserta didik nomor 20 & 73 & 68 \\
21 & Peserta didik nomor 21 & $65^{*}$ & 68 \\
22 & Peserta didik nomor 22 & $50^{*}$ & 68 \\
23 & Peserta didik nomor 23 & $28^{*}$ & 68 \\
24 & Peserta didik nomor 24 & $60^{*}$ & 68 \\
25 & Peserta didik nomor 25 & $45^{*}$ & 68 \\
26 & Peserta didik nomor 26 & 68 & 68 \\
27 & Peserta didik nomor 27 & $35^{*}$ & 68 \\
28 & Peserta didik nomor 28 & $63^{*}$ & 68 \\
29 & Peserta didik nomor 29 & 73 & 68 \\
30 & Peserta didik nomor 30 & 73 & 68 \\
31 & Peserta didik nomor 31 & 68 & 68 \\
32 & Peserta didik nomor 32 & 68 & 68 \\
33 & Peserta didik nomor 33 & $43^{*}$ & 68 \\
34 & Peserta didik nomor 34 & 68 & 68 \\
\hline
\end{tabular}

Keterangan :

*) peserta didik yang belum mencapai Kriteria Ketuntasan Minimal (KKM) 68

Rumus dalam menentukan prosentase peningkatan kemampuan pada peserta didik dalam kelas adalah sebagai berikut:

$$
\begin{aligned}
& P=\frac{F}{N} \times 100 \% \\
& P=\frac{13}{34} \times 100 \% \\
& P=38,23 \%
\end{aligned}
$$

\section{Keterangan:}

\section{$\mathrm{P}=$ Prosentase}

F = Jumlah siswa yang mencapai KKM (Kriteria Ketuntasan Minimal)

$\mathrm{N}=$ Jumlah siswa dalam kelas

Maka berdasar hasil pada Ulangan Harian I dengan materi Personal Letter pada soal bagian B dengan tipe soal persamaan kata (sinonim) ditemukan hasil 38,23 \% dari total peserta yang mencapai nilai Ketuntasan Kriteria Minimal (KKM) 68.

Selama proses pembelajaran dilakukan tahap observasi dengan mencatat hal-hal yang diamati selama kegiatan pembelajaran dan aktivitas guru maupun peserta didik selama pelaksanaan pembelajaran. Tahap observasi ini dilakukan untuk mengetahui kemampuan penguasaan kosa kata peserta didik setelah diaplikasikan media flash card pada mata pelajaran Bahasa Inggris. Pada tahap ini dilaksanakan proses observasi terhadap pelaksanaan tindakan dengan menggunakan lembar observasi yang telah dibuat dengan tujuan untuk melihat efektivitas penerapan media pembelajaran yang telah digunakan.

Dari hasil observasi yang dilakukan peneliti bahwa pembelajaran menggunakan media flash card sudah berjalan akan tetapi belum maksimal, diantaranya karena; kurangnya partisipasi peserta didik dalam kelas karena ini merupakan pertemuan pertama untuk materi yang baru dikenal peserta didik, peserta didik kurang aktif dalam mengajukan pertanyaan, masih ada beberapa peserta didik yang masih mengalami kesulitan dalam memahami materi pelajaran, adanya sebagian siswa yang tidak merespon ketika peneliti menugaskan untuk mengikuti proses pembelajaran dikarenakan siswa masih belum siap untuk belajar dan terkadang setiap peserta didik malas dalam menghafal kosakata yang ada dalam Flash Card.

Pembelajaran dengan media flash card memberikan manfaat bagi peserta didik dalam kemampuan kosakata Bahasa Inggris pada teks, diantaranya sebagai berikut; terciptanya kelas yang aktif dan menyenangkan karena media yang menarik minat peserta didik untuk belajar kosakata baru, meningkatkan penguasaan kosakata sulit yang ditemukan peserta didik dalam teks, meningkatkan hasil belajar peserta didik sehingga didapat nilai mencapai KKM (Kriteria Ketuntasan Minimal)

Hasil peningkatan kemampuan penguasaan kosakata Bahasa Inggris pada peserta didik dapat di lihat pada tabel dibawah ini: 
Tabel 3. Daftar nilai kemampuan penguasaan kosakata Bahasa Inggris peserta didik

\begin{tabular}{|c|c|c|c|c|c|}
\hline No & Nama Peserta Didik & $\begin{array}{l}\text { Nilai KKM (Kriteria } \\
\text { Ketuntasan Minimal) }\end{array}$ & Nilai Awal & $\begin{array}{l}\text { Post test } \\
\text { cycle } 1\end{array}$ & $\begin{array}{l}\text { Post test } \\
\text { cycle } 2\end{array}$ \\
\hline 1 & Peserta didik 1 & 68 & 60 & 70 & 70 \\
\hline 2 & Peserta didik 2 & 68 & 60 & 70 & 70 \\
\hline 3 & Peserta didik 3 & 68 & 50 & 50 & 50 \\
\hline 4 & Peserta didik 4 & 68 & 70 & 80 & 93 \\
\hline 5 & Peserta didik 5 & 68 & 60 & 50 & 73 \\
\hline 6 & Peserta didik 6 & 68 & 70 & 50 & 57 \\
\hline 7 & Peserta didik 7 & 68 & 50 & 80 & 83 \\
\hline 8 & Peserta didik 8 & 68 & 40 & 70 & 70 \\
\hline 9 & Peserta didik 9 & 68 & 55 & 50 & 70 \\
\hline 10 & Peserta didik 10 & 68 & 60 & 70 & 73 \\
\hline 11 & Peserta didik 11 & 68 & 45 & 70 & 73 \\
\hline 12 & Peserta didik 12 & 68 & 65 & 50 & 70 \\
\hline 13 & Peserta didik 13 & 68 & 70 & 70 & 77 \\
\hline 14 & Peserta didik 14 & 68 & 40 & 60 & 60 \\
\hline 15 & Peserta didik 15 & 68 & 65 & 70 & 73 \\
\hline 16 & Peserta didik 16 & 68 & 90 & 90 & 90 \\
\hline 17 & Peserta didik 17 & 68 & 60 & 70 & 73 \\
\hline 18 & Peserta didik 18 & 68 & 70 & 70 & 70 \\
\hline 19 & Peserta didik 19 & 68 & 68 & 70 & 70 \\
\hline 20 & Peserta didik 20 & 68 & 73 & 70 & 77 \\
\hline 21 & Peserta didik 21 & 68 & 65 & 70 & 77 \\
\hline 22 & Peserta didik 22 & 68 & 50 & 60 & 73 \\
\hline 23 & Peserta didik 23 & 68 & 28 & 60 & 70 \\
\hline 24 & Peserta didik 24 & 68 & 60 & 50 & 70 \\
\hline 25 & Peserta didik 25 & 68 & 45 & 60 & 70 \\
\hline 26 & Peserta didik 26 & 68 & 68 & 60 & 60 \\
\hline 27 & Peserta didik 27 & 68 & 35 & 60 & 60 \\
\hline 28 & Peserta didik 28 & 68 & 63 & 60 & 70 \\
\hline 29 & Peserta didik 29 & 68 & 73 & 70 & 70 \\
\hline 30 & Peserta didik 30 & 68 & 73 & 70 & 70 \\
\hline 31 & Peserta didik 31 & 68 & 68 & 70 & 70 \\
\hline 32 & Peserta didik 32 & 68 & 68 & 70 & 70 \\
\hline 33 & Peserta didik 33 & 68 & 43 & 60 & 60 \\
\hline 34 & Peserta didik 34 & 68 & 68 & 70 & 70 \\
\hline \multicolumn{2}{|c|}{ Jumlah } & & 2028 & 2220 & 2402 \\
\hline \multicolumn{2}{|c|}{ Rata-rata } & & 59,65 & 65,29 & 70,65 \\
\hline \multicolumn{2}{|c|}{ Tuntas } & & 13 & 20 & 28 \\
\hline \multicolumn{2}{|c|}{ Belum Tuntas } & & 21 & 14 & 6 \\
\hline
\end{tabular}

Tabel 4. Laporan hasil kemampuan penguasaan kosakata Bahasa Inggris peserta didik

\begin{tabular}{lllllll}
\hline No & Penilaian & \multicolumn{2}{l}{ Jumlah ketuntasan } & Presentase & Rata-rata \\
\cline { 3 - 5 } & & Tuntas & $\begin{array}{l}\text { Belum } \\
\text { Tuntas }\end{array}$ & Tuntas & $\begin{array}{l}\text { Belum } \\
\text { Tuntas }\end{array}$ & \\
\multirow{2}{*}{$\mathbf{1}$} & Pra siklus (nilai & 13 & 21 & $38,23 \%$ & $61,77 \%$ & 59,65 \\
& UH) & & & & & \\
2 & Siklus I & 20 & 14 & $58,82 \%$ & $41,18 \%$ & 65,29 \\
$\mathbf{3}$ & Siklus II & 28 & 6 & $82,35 \%$ & $17,65 \%$ & 70,65 \\
\hline
\end{tabular}

Berdasarkan pada tabel diatas, dapat dilihat pada siklus II, peserta didik yang dapat mencapai Kriteria Ketuntasan Minimal (KKM) adalah 28 peserta didik dan pesetra didik yang belum mencapai Kriteria Ketuntasan Minimal (KKM) berjumlah 6 peserta didik, yang mana dari keseluruhan nilai rata-rata kelas diperoleh 70,65 sedangkan KKM yang ditetapkan untuk mata pelajaran Bahasa Inggris adalah 68. Maka dapat disimpulkan bahwa 44,12\% dari jumlah peserta didik mengalami kenaikan kemampuan penguasaan kosakata. 


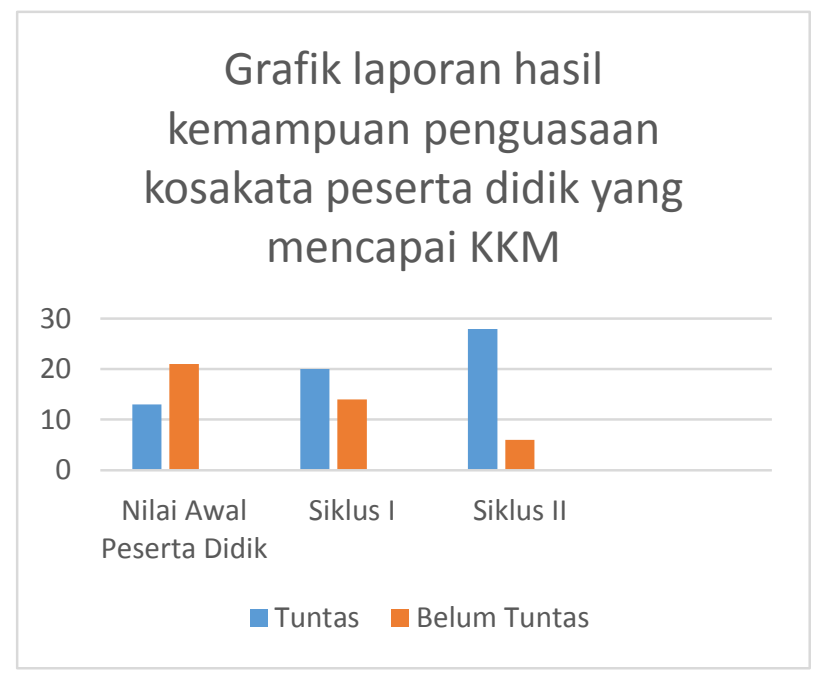

Gambar 1. Grafik Laporan Hasil Kemampuan Penguasaan Kosakata Peserta Didik Yang mencapai KKM pada Pra Siklus, Siklus I, Dan Siklus II.

Berdasarkan tabel dan grafik di atas, dapat dipahami bahwa sebelum penerapan pembelajaran menggunakan media flash card dalam meningkatkan kemampuan penguasaan kosakata peserta didik, nilai kemampuan penguasaan kosa kata peserta didik masih sangat rendah. Data ini diperoleh nilai awal peserta didik dengan jumlah keseluruhan peserta didik 34 orang, diantaranya 13 peserta didik ( 38,23\%) telah mencapai nilai KKM dan 21 peserta didik lainnya (61,77\%) belum mencapai nilai KKM.

Kemudian setelah diterapkan media flash card pada siklus I melalui tahap perencanaan, pelaksanaan, observasi dan refleksi ditemukan bahwa peserta didik mengalami peningkatan dalam penguasaan kosa kata yakni dari jumlah peserta didik 34 orang yang mencapai nilai KKM sebanyak 20 peserta didik $(58,82 \%)$ sedangkan yang belum mencapai nilai KKM ada 14 orang $(41,18 \%)$. Dari data tersebut telah terjadi peningkatan hasil pembelajaran saat media Flash Card digunakan untuk meningkatkan kemampuan penguasaan kosakata peserta didik, namun hasil yang didapat belum mencapai target yang harapkan yakni sebanyak $75 \%$ sehingga perlu diadakannya perbaikan dalam siklus berikutnya. Selanjutnya pada siklus II setelah diadakannya perbaikan dalam hal perencanaan, pelaksanaan, observasi dan refleksi maka terdapat peningkatan yang signifikan dari jumlah peserta didik yang berjumlah 34 orang terdapat 28 peserta didik ( $82,35 \%$ ) yang telah mampu mencapai nilai KKM, sedangkan masih tersisa 6 orang $(17,65 \%)$ dari total peserta didik yang belum mencapai nilai KKM. Berdasarkan data tersebut, dapat disimpulkan bahwa penggunaan media flash card dalam pembelajaran kosakata dapat meningkatkan kemampuan penguasaan kosakata peserta didik sebanyak $44,12 \%$ dari kemampuan rata-rata $38,23 \%$ yang mencapai KKM pada nilai awal menjadi $82,35 \%$ pada nilai post test disiklus II.

\section{Simpulan}

Berdasarkan hasil dan pembahasan penelitian ini dapat disimpulkan bahwa secara umum media Flash Card dapat meningkatkan kemampuan penguasaan kosakata Bahasa Inggris pada peserta didik, nilai rata-rata awal peserta didik hanya mencapai 59,65. Pada siklus I nilai rata-rata meningkat menjadi 65,29, pada siklus kedua terjadi lagi peningkatan rata-rata peserta didik dari siklus I 65,29 menjadi 70,63 pada siklus II maka hasil keseluruhan peningkatan kemampuan penguasaan kosakata peserta didik setelah guru menggunakan Flash Card sebagai media dalam pembelajaran adalah 44,12\% dengan rincian prosentase nilai awal peserta didik yang mencapai KKM (Kriteria Ketuntasan Minimal) adalah 38,23 meningkat menjadi $82,35 \%$ setelah dilakukan penelitian sebanyak dua siklus. Dengan demikian, penggunaan media Flash Card untuk meningkatkan kemampuan penguasaan kosakata peserta didik berhasil karena telah mencapai indikator keberhasilan 75\% dari jumlah peserta didik dalam kelas mencapai KKM (Kriteria Ketuntasan Minimal). Saran yang dapat diberikan dalam penelitian ini adalah guru dapat menggunakan media Flash Card dalam proses pembelajaran untuk meningkatkan kemampuan penguasaan kosakata pada peserta didik, sehingga diharapkan mampu menciptakan suasana belajar yang efektif dan menyenangkan. 


\section{Daftar Pustaka}

ahmad Susanto (2011) Perkembangan Anak Usia Dini: Pengantar Dalam Berbagai Aspeknya. Jakarta: Prenada Media Grup.

Arsyad, A. (2011) Media Pembelajaran. Jakarta: Rajawali Press.

Faridatuunnisa, I. (2020) 'Kebijakan Dan Pelaksanaan Pembelajaran Bahasa Inggris Untuk Sd Di Indonesia.', Seminar Nasional Pendidikan, Pp. 191-199. Available At: Https://Jurnal.Ustjogja.Ac.Id/Index.Php/Semnas2020/Article/View/7510.

Fitriyani, E. And Nulanda, P. Z. (2017) 'Efektivitas Media Flash Cards Dalam Meningkatkan Kosakata Bahasa Inggris', Psympathic: Jurnal Ilmiah Psikologi, 4(2), Pp. 167-182. Doi: 10.15575/Psy.V4i2.1744.

Hasil, M. Et Al. (2012) 'Jurnal Pendidikan Ipa Indonesia Pembelajaran Science-Edutainment Berbantuan Media', 1(2), Pp. 192-197.

Maryanto, R. I. P. And Wulanata, I. A. (2018) 'Penggunaan Media Flashcard Untuk Meningkatkan Pengenalan Bentuk Huruf Siswa Kelas I Pada Mata Pelajaran Bahasa Indonesia Di Sekolah Abc Manado', Pedagogia, 16(3), P. 305. Doi: 10.17509/Pdgia.V16i3.12073.

Nasution, D., Harahap, S., Siregar, S., \& Hasibuan, A. (2021) 'Pendampingan Bahasa Inggris Pada AnakAnak Setingkat Sekolah Dasar Di Desa Wisata Pagaran Gala- Gala, Mandailing Natal- Sumut, Dalam Mengahadapi Masyarakat Ekonomi Asean (Mea) Melalui Metode Drilling Dan Repetition', Jurnal Pengabdian Kepada Masyarakat, 1(2), 63-72. Retrieved from https://stp-mataram.ejournal.id/Amal/article/view/573.

Santosa, P. P. P. (2017) 'Kemampuan Membaca Teks Persuasif Bahasa Inggris Siswa Kelas X Smk Negeri 2 Depok (The Ability To Read Text United Kingdom Language Grade Persuasive X Smk Negeri 2)', Deiksis, 09(02), Pp. 170-181.

Sekarini, W. (2018) Penggunaan Media Flash Card Untuk Meningkatkan Kemampuan Menghafal Kosa Kata Bahasa Arab Siswa Madrasah Ibtidaiyah Terpadu Muhammadiyah 01 Sukarame. Lampung: Universitas Islam Negeri Raden Intan.

Sholichah, A. S. (2018) 'Teori-Teori Pendidikan Dalam Al-Qur'an', Edukasi Islami : Jurnal Pendidikan Islam, 7(01), P. 23. Doi: 10.30868/Ei.V7i01.209. 